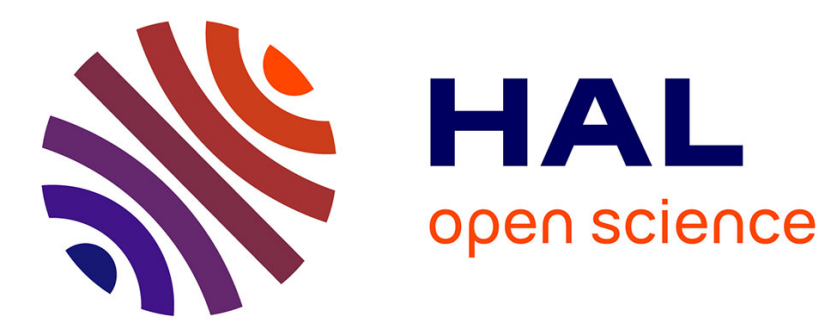

\title{
The Luenberger indicator and productivity growth: A note on the European savings banks sector
}

\author{
Jonathan Williams, Nicolas Peypoch, Carlos Pestana Barros
}

\section{To cite this version:}

Jonathan Williams, Nicolas Peypoch, Carlos Pestana Barros. The Luenberger indicator and productivity growth: A note on the European savings banks sector. Applied Economics, 2009, 43 (6), pp.747. 10.1080/00036840802599859 . hal-00582205

\section{HAL Id: hal-00582205 \\ https://hal.science/hal-00582205}

Submitted on 1 Apr 2011

HAL is a multi-disciplinary open access archive for the deposit and dissemination of scientific research documents, whether they are published or not. The documents may come from teaching and research institutions in France or abroad, or from public or private research centers.
L'archive ouverte pluridisciplinaire HAL, est destinée au dépôt et à la diffusion de documents scientifiques de niveau recherche, publiés ou non, émanant des établissements d'enseignement et de recherche français ou étrangers, des laboratoires publics ou privés. 


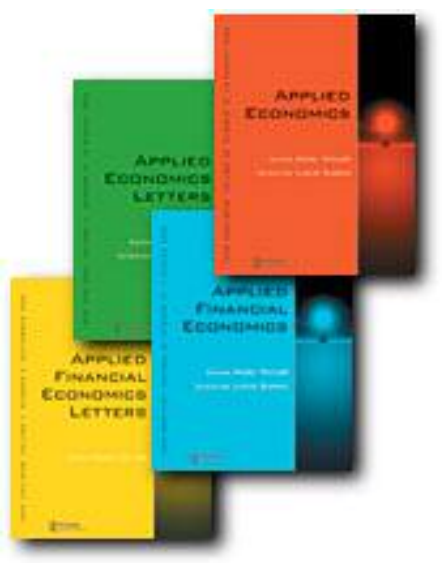

The Luenberger indicator and productivity growth: A note on the European savings banks sector

\begin{tabular}{|c|c|}
\hline Journal: & Applied Economics \\
\hline Manuscript ID: & APE-06-0790.R1 \\
\hline Journal Selection: & Applied Economics \\
\hline $\begin{array}{r}\text { Date Submitted by the } \\
\text { Author: }\end{array}$ & $30-N o v-2007$ \\
\hline Complete List of Authors: & $\begin{array}{l}\text { Williams, Jonathan; University of Wales, Bangor, Business School } \\
\text { Peypoch, Nicolas; Université de Perpignan, GEREM } \\
\text { Barros, Carlos; Technical University of Lisbon, Instituto Superior de } \\
\text { Economia e Gestão }\end{array}$ \\
\hline JEL Code: & $\begin{array}{l}\text { D24 - Production|Capital and Total Factor Productivity|Capacity < } \\
\text { D2 - Production and Organizations < D - Microeconomics, G21 - } \\
\text { Banks|Other Depository Institutions|Mortgages < G2 - Financial } \\
\text { Institutions and Services < G - Financial Economics }\end{array}$ \\
\hline Keywords: & Savings banks, Europe, Productivity, Luenberger indicator \\
\hline
\end{tabular}

\section{s) ScholarONE" \\ Manuscript Central}




\title{
The Luenberger indicator and productivity growth: A note on the European savings banks sector
}

\author{
Jonathan Williams $^{\mathrm{a}}$; Nicolas Peypoch ${ }^{\mathrm{b}}$ and Carlos Pestana Barros ${ }^{\mathrm{c}}$
}

December, 2006

This version: November, 2007

\begin{abstract}
a Centre for Banking and Finance, Business School, Bangor University, Bangor, Gwynedd, UK, LL57 2DG. jon.williams@bangor.ac.uk

b GEREM, Département des Sciences Economiques et de Gestion, Université de Perpignan, 52 avenue Paul Alduy, F-66860 Perpignan, France, peypoch@univ-perp.fr

c Instituto Superior de Economia e Gestão, Technical University of Lisbon, Rua Miguel Lupi, 20,1249-068 Lisbon, Portugal, cbarros@iseg.utl.pt
\end{abstract}

\begin{abstract}
We employ the Luenberger productivity indicator to estimate productivity growth and its decomposition into technical change and efficiency change components for savings banks sectors in ten EU countries between 1996 and 2003. The Luenberger indicator requires less restrictive assumptions than standard non-parametric productivity indexes, and it allows the assumption of profit maximisation to be made for sample firms. We estimate average productivity growth in the savings banks sector to be 2.78 percent per annum and driven almost entirely by technical change. Whilst the general results confirm earlier findings, this study is one of the earliest to identify cross-border differences in productivity growth in the savings banks sector.
\end{abstract}

Keywords: Europe; savings banks; Luenberger productivity indicator.

JEL Classification: G21, D24

Corresponding author: J. Williams, Business School, Bangor University, Bangor, Gwynedd, UK, LL57 2DG. jon.williams@bangor.ac.uk 


\section{Introduction}

The EU financial deregulation process constituted a major structural change that altered the competitive environment of the European banking system. As banking market structures become more liberalised, it is expected that these changes would feed through into competition, efficiency gains and productivity improvements for banks (Molyneux and Williams, 2005). The issue of productivity measurement is long debated. Following Nishimizu and Page (1982), total factor productivity change is decomposed into technological progress (the rate of change of the best practice frontier) and technical efficiency change (learning-by-doing, improved managerial practice as firms attempt to catch-up with industry best practice). A remaining question is how best to estimate productivity change.

Whilst productivity change can be determined by parametric and non-parametric methods (Odeck, 2007, and Casu et al, 2004 provide comparisons of estimated productivity growth derived from frontier methods and data envelopment analysis), the non-parametric Malmquist productivity index is used in several applications in banking (see Guzmán and Reverte, 2007). A drawback of the Malmquist approach is that it requires a choice to be made between an output or input perspective, which depends on the assumption of either revenue maximisation or cost minimisation at sample firms but not profit maximisation (Boussemart et al, 2003). This limiting assumption does not hold if productivity change is estimated using the Luenberger productivity indicator, which is a difference-based indicator as opposed to ratiobased like the Malmquist. ${ }^{1}$ In its favour, the Luenberger indicator can account for output expansion and input contraction whilst assuming that sample firms maximise

\footnotetext{
${ }^{1}$ For further elaboration on productivity measurement by ratios (indexes) and differences (indicators), see Chambers (1996, 2002) and Diewert (2000, 2005).
} 
profit. Evidence shows that ratio-based productivity indexes overestimate productivity change compared to productivity indicators (Briec and Kerstens, 2004; Boussemart et al, 2003, 2006).

We apply the Luenberger indicator to estimate productivity change in the European savings banks sector between 1996 and 2003. ${ }^{2}$ Various implications for public policy arise from the productivity performance of savings banks (Williams, 2004). There is the need to establish if the deregulation model is achieving its intended effects on savings banks, which, typically, are small-sized banks serving local retail banking customers, and whose ownership rights are often ambiguous implying that the disciplining effect of the market for corporate control is absent. ${ }^{3}$ For savings banks, the decomposition of productivity change can show to what extent national group organisational structures and their technology sharing arrangements benefit all savings banks irrespective of size. Productivity growth, attained by technological progress and/or efficiency gains, is an important goal for savings banks that target cost savings as transfers to reserves, which are intended to lessen the long standing capitalisation problems facing the sector.

The remainder of the paper is organized as follows: Section 2 synthesises the salient literature. The methodology is detailed in Section 3. Section 4 presents the data and the results whilst some conclusions are offered in Section 5.

\footnotetext{
${ }^{2}$ So far as we are aware, there is one other application of the Luenberger productivity indicator in banking (see Park and Weber, 2006 for a study of productivity growth in Korean banks).

${ }^{3}$ The role of savings banks varies across countries: in the EU savings banks account for roughly $25 \%$ of non-bank customer deposits, $50 \%$ in Spain and around $40 \%$ in Germany (as at January 2006).
} 


\section{Bank efficiency, technical change and productivity growth}

The empirical literature on European savings banks estimates bank efficiency, technical change and productivity change, with the bulk of studies concerned with estimating the level of efficiency. Carbo et al (2002), for instance, in a cross-country study use parametric methods to estimate the cost efficiency of EU savings banks between 1989 and 1996. They report an average cost inefficiency of around $22 \%$ with cross-country variations. Williams and Gardener (2003) also use parametric methods and report relatively low levels of cost inefficiency (7\%), implying that “ ... regional bank management is responsive to changing market conditions with prudently managed banks becoming more cost efficient" (Williams and Gardener, 2003, p. 327). Other EU-wide studies seek to draw inferences about the efficiency performance of savings banks and commercial banks. Schure et al (2004) find on average that savings banks can reduce costs by between $15-20 \%$ compared with 20 $25 \%$ for commercial banks. Consistent with Carbo et al (2002), Schure et al (2004) report considerable heterogeneity in cross-border inefficiencies. Single country studies tend to examine if bank organisational form explains efficiency differences. Evidence from Germany, where there is a large public-owned savings banks sector, implies the results are inconclusive (Altunbas et al, 2001).

Another strand of literature estimates the effect of technical change on bank costs. For the EU banking industry, Altunbas et al (2001) estimate that technical change lowered bank costs by 3.6\% per annum between 1989 and 1996. In a study of the savings banks sector between 1989 and 1997, Carbo et al (2003) report a similar per annum reduction in bank cost of 3.4\%. Wagenvoort and Schure (1999) report a similar finding that savings banks costs fell by $2 \%$ per annum because of 
technological progress. Evidence from the Spanish savings banks sector confirms the generalisation that technical change has lowered bank costs (Maudos et al, 1996).

European banks, in general, are realising productivity improvements, although the rate of growth varies across countries, possibly reflecting differences in the pace of banking sector consolidation (see Dietsch and Weill, 2000; Casu et al, 2004; Molyneux and Williams, 2005). This contrasts with evidence from the US that suggests productivity growth is limited (see Bauer et al, 1993; Humphrey and Pulley, 1997; Stiroh, 2000; Alam, 2001; Berger and Mester, 2003). US evidence finds a positive relationship between financial deregulation and profit productivity but the opposite for cost productivity (Berger and Mester, 2003). In Europe, the evidence is mixed: Kumbhakar et al (2001) and Kumbhakar and Lozano-Vivas (2005) find deregulation led to productivity growth in the Spanish savings banks sector but the opposite is reported by Griffel-Tatjé and Lovell (1997). This is attributed to differences in the specification of banks' output vectors.

In order to identify the sources of productivity change in the European savings banks sectors in six EU countries between 1990 and 1998, Williams (2001) uses parametric methods and finds mean growth of $2.86 \%$ per annum with technical change the main driver. Casu et al (2004) confirm the role played by technical change in driving productivity growth at a large sample of European banks, and supported by both parametric and non-parametric estimates. Similar results are observed for large US commercial banks (Mukherjee et al, 2001); Swedish banks (Kumbhakar et al, 2002); savings banks (Dietsch and Weill, 2000; Kumbhakar et al, 2001) and banks in general in Spain (Guzmán and Reverte, 2007). 


\section{Methodological Framework}

\subsection{Technology, directional distance function \& Luenberger productivity indicator}

Chambers et al $(1996,1998)$ propose more flexible measures of firm performance deriving from production theory. They introduced the "directional distance function", which is the transposition in production theory of Luenberger's "benefit function" in a consumer context (see Luenberger, 1992). This function determines a distance in one direction which permits an observed production unit to reach the production frontier. In economic terms, the function makes it possible to evaluate the economies which can be achieved, and the possible improvements in production; it also provides a "benchmark" by defining a reference point to be reached. The principal advantage of this function lies in its ability to take account simultaneously, and in a broader context, of both inputs and outputs. The directional distance function, therefore, measures the largest changes in inputs and outputs in a given direction which are necessary for a firm to reach the production frontier.

Let the technology be described by a set, $T_{t}^{k} \subseteq R_{+}^{n} \times R_{+}^{p}$, defined by

$$
T_{t}^{k}=\left\{\left(x_{t}^{k}, y_{t}^{k}\right): x_{t}^{k} \text { can produce } y_{t}^{k}\right\}
$$

where $x_{t}^{k} \in R_{+}^{n}$ is a vector of inputs and $y_{t}^{k} \in R_{+}^{p}$ is a vector of outputs at the time period $t$ for the bank $k$.

Throughout this paper, technology satisfies the following conventional assumptions:

A1: $(0,0) \in T_{t}^{k},\left(0, y_{t}^{k}\right) \in T_{t}^{k} \Rightarrow y_{t}^{k}=0$ i.e., no free lunch;

A2: the set $A\left(x_{t}^{k}\right)=\left\{\left(u_{t}^{k}, y_{t}^{k}\right) \in T_{t}^{k} ; u_{t}^{k} \leq x_{t}^{k}\right\}$ of dominating observations is bounded $\forall x_{t}^{k} \in R_{+}^{N}$, i.e., infinite outputs are not allowed with a finite input vector; 
A3: $T_{t}^{k}$ is closed;

A4: $\forall\left(x_{t}^{k}, y_{t}^{k}\right) \in T_{t}^{k},\left(x_{t}^{k},-y_{t}^{k}\right) \leq\left(u_{t}^{k},-v_{t}^{k}\right) \Rightarrow\left(u_{t}^{k}, v_{t}^{k}\right) \in T_{t}^{k}$, i.e., fewer outputs can always be produced with more inputs, and inversely (strong disposal of inputs and outputs);

A5: $T_{t}^{k}$ is convex.

The directional distance function generalizes the traditional Shephard (1970) distance function. Directional distance functions project input and output vectors from themselves to the technology frontier in a pre-assigned direction. In the case of a radial direction out of the origin, we retrieve the classical Shephard distance function. The directional distance function is defined as follows:

The function $D_{t}^{k}: R^{n+p} \times R^{n+p} \rightarrow R \cup\{-\infty\} \cup\{+\infty\}$ defined by

$$
D_{t}^{k}\left(x_{t}^{k}, y_{t}^{k} ; g\right)= \begin{cases}\sup \left\{\delta:\left(x_{t}^{k}-\delta h ; y_{t}^{k}+\delta l\right) T_{t}^{k}\right\} & \text { if } \\ -\infty & \left(x_{t}^{k}-\delta h ; y_{t}^{k}+\delta l\right) \in T_{t}^{k}, \delta \in R \\ \text { otherwise }\end{cases}
$$

is called directional distance function in the direction of $g=(h, l)$.

To operate the approach, it is necessary to take an appropriate direction. We do this by considering the direction $g=(x, y)$. Then, the directional distance function is similar to the proportional distance function of Briec (1997). This distance function is based on simultaneous proportional modifications of inputs and outputs; it generalizes the Debreu and Farrell measures and is straightforward to interpret. 
One of the most important properties of the production technology is its dual relation to the profit function. The profit function $\Pi: R_{+}^{n+p} \rightarrow R \cup\{\infty\}$ is defined as:

$$
\Pi_{t}^{k}(r, w)=\sup _{x^{k}, y^{k}}\left\{r y_{t}^{k}-w x_{t}^{k}:\left(x_{t}^{k}, y_{t}^{k}\right) \in T_{t}^{k}\right\}
$$

where $r \in R_{+}^{p}$ is the output price vector and $w \in R_{+}^{n}$ is the input price vector. Suppose that an individual bank is represented by a production $\operatorname{vector}\left(x_{t}^{k}, y_{t}^{k}\right)$ with corresponding technology $T_{t}^{k}$, and then the production vector is changed to $\left(x_{t+1}^{k}, y_{t+1}^{k}\right)$ with corresponding technology $T_{t+1}^{k}$. In order to assign a cardinal measure to the productivity change we can use the directional distance function in one of two ways; corresponding to using either the initial technology at $t$ or the final technology at $t+1$ as reference. In this case, the Luenberger productivity indicator proposed by Chambers (1996) can be employed to evaluate productivity change. The productivity indicator is constructed as the arithmetic mean of the productivity change measured by the technology at $T_{t+1}$ and the productivity change measured by the technology at $T_{t}$.

The Luenberger productivity indicator is defined as ${ }^{4}$ :

$$
L\left(z_{t}, z_{t+1}\right)=\frac{1}{2}\left[D_{t+1}\left(z_{t} ; g\right)-D_{t+1}\left(z_{t+1} ; g\right)+D_{t}\left(z_{t} ; g\right)-D_{t}\left(z_{t+1} ; g\right)\right] .
$$

Positive growth (decline) is indicated by positive (negative) value. Unlike the Malmquist index, the Luenberger productivity indicator is additively decomposed:

$$
\begin{aligned}
L\left(z_{t}, z_{t+1}\right)= & {\left[D_{t}(z ; g)-D_{t+1}\left(z_{t+1} ; g\right)\right]+} \\
& \frac{1}{2}\left[D_{t+1}\left(z_{t+1} ; g\right)-D_{t}\left(z_{t+1} ; g\right)+D_{t+1}\left(z_{t} ; g\right)-D\left(z_{t} ; g\right)\right],
\end{aligned}
$$

\footnotetext{
${ }^{4}$ We simplify the notations by posing $z_{t}=\left(x_{t}, y_{t}\right)$.
} 
where the first term (inside the first brackets) measures efficiency change between time periods $t$ and $t+1$ while the arithmetic mean of the difference between the two figures inside the second brackets expresses the technological change component, which represents the shift of technology between the two time periods. This decomposition was inspired by the multiplicative breakdown of the Malmquist productivity index (see Färe et al, 1989).

\subsection{Structural efficiency and aggregation}

In an aggregate context, and following Farrell (1957) and Briec et al (2003), we use an aggregate directional distance function constructed as:

$$
D_{t}\left(\sum_{k=1}^{K} x_{t}^{k}, \sum_{k=1}^{K} y_{t}^{k}\right)
$$

This aggregate efficiency indicator is referred to as a structural efficiency indicator, and the aggregate Luenberger productivity indicator $(A L)$ is constructed as follows: ${ }^{5}$

$$
A L\left(\sum_{k=1}^{K} z_{t}^{k}, \sum_{k=1}^{K} z_{t+1}^{k}\right)=\frac{1}{2}\left[D_{t+1}\left(\sum_{k=1}^{K} z_{t}^{k}\right)-D_{t+1}\left(\sum_{k=1}^{K} z_{t+1}^{k}\right)+D_{t}\left(\sum_{k=1}^{K} z_{t}^{k}\right)-D_{t}\left(\sum_{k=1}^{K} z_{t+1}^{k}\right)\right] .
$$

Equation (7) allows similar decompositions to equation (5).

Farrell (1957) was the first to propose the concept of "structural efficiency" to measure the overall efficiency of an industry (as a group of firms). In a radial context, he suggested that it can be measured by the weighted average (by output) of the efficiency scores of individual units. Along this line, several studies clarify and develop a framework for the measurement of structural efficiency (see, for instance, Førsund and Hjalmarsson, 1979; Färe, Grosskopf, and Li, 1992; Li and Ng, 1995;

\footnotetext{
${ }^{5}$ See Färe and Primont (2003) and Färe and Grosskopf (2004) for discussion of the aggregation of the Luenberger productivity indicator.
} 
Ylvinger, 2000; Färe and Zelenyuk, 2003; Li and Cheng, 2007). The different developments are based on the fact that the group of firms has an identical technology, which is a common assumption in efficiency analysis.

In a directional distance function framework, the aggregation of efficiency measures is investigated by Briec et al (2003) and Färe and Grosskopf (2004). However, these authors do not study fully the specific case of structural efficiency, and especially how the aggregate technology is constructed according to the returns to scale. To overcome this problem and define our aggregate technology, we follow Briec and Peypoch (2004) and show the equivalence between structural and industrial efficiency by employing Koopmans (1957) theorem.

The resource directional distance function proposed by Briec and Peypoch (2004) is the transposition in a production context of the resource function introduced by Luenberger (1996) in order to analyse the consumer's welfare from an aggregate viewpoint.

The resource directional distance function $R: R_{+}^{n+p} \times R_{+}^{n+p} \rightarrow R \cup\{-\infty\} \cup\{+\infty\}$ is defined as ${ }^{6}$ :

$$
R_{t}\left(x_{t}^{j}, y_{t}^{j} ; g\right)=\sup \left\{\sum_{k=1}^{K} D_{t}^{k}\left(x_{t}^{k}, y_{t}^{k} ; g\right):\left(\sum_{k \in K_{j}} x_{t}^{k}, \sum_{k \in K_{j}} y_{t}^{k}\right)=\left(x_{t}^{j}, y_{t}^{j}\right)\right\}
$$

where the production choice for a group of banks $j$ (at the country level in our case) is denoted by $z_{t}^{j}=\left(x_{t}^{j}, y_{t}^{j}\right)=\prod_{k \in K_{j}}\left(x_{t}^{k}, y_{t}^{k}\right)$. 
Assume that for $k=1, \ldots, K, T_{t}^{k}$ satisfies A1-A5 (see page 7) at each time period $t$ and denote $T_{t}=\sum_{k=1}^{K} T_{t}^{k}$ the aggregate technology. Then, the structural efficiency indicator in equation (6) is equal to the resource directional distance function defined by equation (9).

Koopmans (1957) provides a useful result that pertains to aggregation across units. If each of $K$ banks maximizes profit, we have:

$$
\Pi_{t}^{k}(r, w)=\max _{x^{k}, y^{k}}\left\{r y_{t}^{k}-w x_{t}^{k}:\left(x_{t}^{k}, y_{t}^{k}\right) \in T_{t}^{k}\right\}, k=1, \ldots, K .
$$

By choosing $\left(x_{t}^{k^{*}}, y_{t}^{k^{*}}\right), k=1, \ldots, K$, then

$$
\left(x_{t}^{k^{*}}, y_{t}^{k^{*}}\right)=\left(\sum_{k=1}^{K} x_{t}^{k^{*}}, \sum_{k=1}^{K} y_{t}^{k^{*}}\right)
$$

maximizes profit on the aggregate technology set,

$$
\Pi_{t}(r, w)=\max _{x, y}\left\{r y_{t}-w x_{t}:\left(x_{t}, y_{t}\right) \in T_{t}\right\}
$$

Conversely, if $\left(x_{t}^{*}, y_{t}^{*}\right)$ maximizes profit on $T$ and if there are $\operatorname{vectors}\left(x_{t}^{k^{*}}, y_{t}^{k^{*}}\right), k=1, \ldots, K$, such that

$$
\left(x_{t}^{*}, y_{t}^{*}\right)=\left(\sum_{k=1}^{K} x_{t}^{k^{*}}, \sum_{k=1}^{K} y_{t}^{k^{*}}\right)
$$

then each bank level vector, $\left(x_{t}^{k^{*}}, y_{t}^{k^{*}}\right)$, maximizes profit on $T_{t}^{k}, k=1, \ldots, K$. If we define the directional distance function for the aggregate technology by:

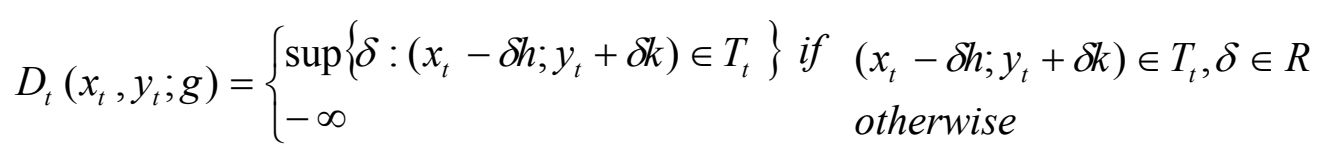

\footnotetext{
${ }^{6}$ See also Guironnet and Peypoch (2007) for an empirical contribution using this measure.
} 
it is straightforward to prove that $D(x, y ; g)=R(x, y ; g)$. In words, the aggregation that takes place here is exactly the same as discussed by Koopmans (1957).

To estimate each aggregate efficiency indicator, we use a non-parametric approach (see Banker and Maindiratta, 1988; Varian, 1984). The technology can be written as:

$$
\forall k \in K, T^{k}=T^{K}=\left\{(x, y), x \geq \sum_{k \in K} \theta_{k} x^{k}, y \leq \sum_{k \in K} \theta_{k} y^{k}, \sum_{k \in K} \theta_{k}=1, \theta \geq 0\right\} .
$$

The aggregate indicator requires the calculation of the aggregate technology and allows us to compare the banks of a country with the set of all banks of all countries. The linear program that calculates the values of the aggregate directional distance function is given $\mathrm{by}^{7}$ :

$$
\begin{aligned}
& R_{t}\left(z_{t}^{j}\right)=\max \sum_{k \in K_{j}} \delta_{t}^{k} \\
& \text { s.t. } x_{t}^{k}-\delta_{t}^{k} g \geq \sum_{k \in K} \theta_{k} x_{t}^{k}, k \in K_{j} \\
& \qquad y_{t}^{k}+\delta_{t}^{k} g \leq \sum_{k \in K} \theta_{k} y_{t}^{k}, k \in K_{j} \\
& \sum_{k} \theta_{k}=1, \theta_{k} \geq 0, \delta_{t}^{k} \geq 0 \\
& \sum_{k_{j} \in K_{j}} x_{t}^{k_{j}}=x_{t}^{j}, \sum_{k_{j} \in K_{j}} y_{t}^{k_{j}}=y_{t}^{j} .
\end{aligned}
$$

Note that the constraint $\sum_{k} \theta_{k}=1$ represents variable returns to scale.

\footnotetext{
${ }^{7}$ All the computations are programmed in Mathematica language with the Mathematica 5.0 software.
} 


\section{Data and empirical estimates of productivity change}

The financial statements of European savings banks from ten EU countries are sourced from BankScope between 1996 and 2003 yielding 5,721 observations (see Table 1 for the distribution of sample data).

Table 1 here

We construct aggregate efficiency and productivity measures for saving banks in each country. To model the bank production process, we employ the intermediation approach of Sealey and Lindley (1977) which assumes that bank liabilities are transformed into earning assets. ${ }^{8}$ Banks are assumed to produce four outputs that cover both on and off-balance sheet activities: (i) total customer loans, (ii) interbank loans, (iii) securities, and (iv) off-balance-sheet items. ${ }^{9}$ Two inputs are used to produce bank output: (v) fixed assets and (vi) variable cost (defined as the sum of interest expense, personnel cost, and other non-interest income expense). The descriptive statistics are shown in Table 2.

Table 2 here

The aggregate Luenberger productivity indicators are calculated using linear programming techniques and the results presented in Table 3. The productivity indicator $(\mathrm{AL})$ is decomposed into its constituents: technical efficiency change (the diffusion or catch-up component - EFFCH); and technological change (the innovation or frontier-shift component - TECH). EFFCH represents the diffusion of best-practice technology in the management of banking activities and it is attributable to investment planning, technical experience, and management and

\footnotetext{
${ }^{8}$ There are several approaches to modelling the bank production process: the production approach, user-cost approach, value added approach and dual approach (see Berger and Humphrey, 1992).

${ }^{9}$ Our choice of bank output is consistent with the established literature. This is important because the definition and measurement of output could significantly affect the level of bank efficiency (Berger and Humphrey, 1997).
} 
organization. TECH results from innovations and the adoption of new technologies by best-practice banks in each country.

The average annual rate of productivity growth for EU savings banks between 1996 and 2003 is 2.79 percent. This estimate is slightly lower, yet consistent with the 2.86 percent reported for six EU savings banks sectors between 1990 and 1998 (Williams, 2001). This implies that savings banks are achieving productivity growth across the current period of EU financial deregulation. Consistent also with evidence on savings banks (Williams, 2001; Maudos et al, 1996), our results confirm technical change (at 2.74 percent) is the main source of productivity growth. Our technical change estimate is slightly lower than the 3.4 percent per annum reported for the sector between 1989 and 1997 (Carbo et al, 2003) and for European banks between 1989 and 1996 of 3.6 percent per annum (Altunbas et al, 2001). Nevertheless, the result implies that the benefits of savings banks' technology sharing arrangements extend across all banks. The results show there is a limited contribution made to productivity growth by efficiency change (0.323 percent). However, efficiency change is contributing, which contrasts with earlier evidence (Williams, 2001).

This study reports cross-country estimates of productivity change for savings banks sectors. So far as we are aware, this is the first study to estimate productivity change and its decomposition for the European savings banks sector. As might be expected, the results displayed in Table 3 exhibit cross-country heterogeneity. Productivity growth is highest in Finland (4.53 percent), Spain (4.488 percent) and France (4.223 percent) yet negative in Germany (-1.688 percent).

Table 3 here 
As noted above, productivity growth in savings banks sectors is almost entirely driven by technical change, with the exception of Italy, Portugal and Spain. This implies that savings banks are benefiting from investment in new technologies (methodologies, procedures and techniques) and in the commensurate skills upgrades related to this. However, the finding of zero efficiency change in several sectors is a source of concern for bankers and policymakers because it implies that management is lagging behind observed best practice. Although benefiting from technical change, the average savings banks in Italy (0.53 percent), Portugal (0.82 percent) and Spain (1.871 percent) are catching-up to best practice.

From the results we observe three distinct combinations of technical change and efficiency change. First, there are three sectors where improvements in technical efficiency co-exist alongside improvements in technological change: in Portugal, Spain and Italy. We class these savings banks as the best-performing banks between 1996 and 2003. Second, we observe six sectors in which zero technical efficiency change co-exist with improvements in technological change: in Austria, Belgium, Finland, France, Luxembourg and Netherlands. Finally, in Germany, zero efficiency change co-exists with deterioration in technological change.

\section{Conclusion}

We employ the Luenberger productivity indicator rather than commonly applied non-parametric indexes for two reasons. Indexes overestimate productivity change relative to difference-based indicators like the Luenberger. The assumption that sample firms maximise profits is accommodated by the Luenberger indicator. Our application is to the savings banks sectors in ten EU countries from 1996 to 2003. 
The results show that the average savings bank achieved annualised productivity growth of 2.79 percent over the period. This rate of growth is consistent with previous findings for savings banks drawn from parametric models (Williams, 2001). With regard to public policy, our results suggest that financial deregulation is positively associated with bank productivity growth, which confirms earlier evidence from Spain (Kumbhakar et al, 2001; Kumbhakar and Lozano-Vivas, 2005); the US (Berger and Mester, 2001); and some EU savings banks sectors (Williams, 2001). The implication is that EU financial deregulation has lowered production costs, which translated into cost savings that have been reflected in productivity growth.

The main source of productivity growth for savings banks is technical change, which confirms other findings for savings banks (Williams, 2001) and European banks (Casu et al, 2004). The productivity-driving role of technical change is all the more important given there is minimal evidence that suggests savings banks are catching up with best practice. Possible reasons for this finding include the absence of a disciplining market for corporate control, and possible agency problems arising from public and/or mutual ownership. Whilst this would concern bank regulators, it may be partially offset by the fact that productivity growth can be used to support capitalisation of non-joint stock savings banks. 


\section{References}

Alam, I.M.S., 2001. A Non-Parametric Approach for Assessing Productivity Dynamics of Large Banks. Journal of Money, Credit and Banking 33, 121 - 139.

Altunbaş, Y., Evans, L., Molyneux, P., 2001. Bank ownership and efficiency. Journal of Money, Credit and Banking 33, 4, 926-954.

Banker, R.D., Maindiratta, A., 1988. Nonparametric analysis of technical and allocative efficiency in production. Econometrica 56, 1315-1332.

Bauer, P.W., Berger, A.N., Humphrey, D.B., 1993. Efficiency and Productivity Growth in US Banking, in Fried, H.O., Lovell, C.A.K., Schmidt, S.S., (eds.), The Measurement of Productive Efficiency: Techniques and Applications. Oxford University Press, Oxford, 386-413.

Berger, A.N., Humphrey, D.B., 1992. Measurement and efficiency issues in commercial banking. In Z. Griliches (ed) Output Measurement in the Service Sectors, National Bureau of Economic Research (Chicago: University of Chicago Press), 245-279.

Berger, A.N., Humphrey, D.B., 1997. Efficiency of financial institutions: international survey and directions for future research. European Journal of Operational Research 98, 2, April, 175-212. 
Berger, A.N., Mester, L.J., 2003. Explaining the Dramatic Changes in Performance of US Banks: Technological Change, Deregulation, and Dynamic Changes in Competition. Journal of Financial Intermediation 12, 1, 57-95.

Briec, W., Kerstens, K., 2004. A Luenberger-Hicks-Moorsteen productivity indicator: its relation to the Hicks-Moorsteen productivity index and the Luenberger productivity indicator. Economic Theory 23, 925-939.

Boussemart, J.P., Briec, W., Kerstens, K., Poutineau, J.C., 2003. Luenberger and Malmquist productivity indices: Theoretical comparisons and empirical illustration. Bulletin of Economic Research 55, 391-405.

Boussemart, J.P., Briec, W., Peypoch, N., Tavéra, C., 2006. $\alpha$-returns to scale and multi-output technologies. Unpublished paper, Université de Perpignan.

Briec, W., 1997. A graph type extension of Farrell technical efficiency measure. Journal of Productivity Analysis 8, 95-110.

Briec, W., Dervaux, B., Leleu, H., 2003. Aggregation of directional distance functions and industrial efficiency. Journal of Economics 79, 237-261.

Briec, W., Kerstens, K., 2004. A Luenberger-Hicks-Moorsteen productivity indicator: its relation to the Hicks-Moorsteen productivity index and the Luenberger productivity indicator. Economic Theory 23, 925-934. 
Briec, W., Peypoch, N., 2004. An aggregate productivity index and its virtual price correspondence. Working Paper n. 13-F/2003.GEREM, University of Perpignan.

Carbo, S, Gardener, E.P.M., Williams, J., 2002. Efficiency in Banking: Empirical Evidence from the Savings Banks Sector. The Manchester School 70, 2, March, 204228.

Carbo, S, Gardener, E.P.M., Williams, J., 2003. A Note on Technical Change in Banking: The Case of European Savings Banks. Applied Economics 35, 705-719.

Casu, B., Girardone, C., Molyneux, P., 2004. Productivity in European banking - A comparison of parametric and non-parametric approaches. Journal of Banking \& Finance 28, 10, 2521-2540.

Chambers, R.G., 1996. A new look at exact input, output, and productivity measurement. Department of Agricultural and Resource Economics, Working Paper 96-05, University of Maryland.

Chambers, R.G., 2002. Exact nonradial input, output, and productivity measurement. Economic Theory 20, 751-765.

Chambers, R.G., Chung, Y., Färe, R., 1996. Benefit and distance functions. Journal of Economic Theory 70, 407-419. 
Chambers, R.G., Chung, Y., Färe, R., 1998. Profit, directional distance functions, and Nerlovian efficiency. Journal of Optimization Theory and Applications 98, 351364.

Dietsch, M., Weill, L., 2000. The Evolution of Cost and Profit Efficiency in the European Banking Industry, Research in Banking and Finance, JAI Press.

Diewert, W., 2000. Productivity measurement using differences rather than ratios: A Note. School of Economics Discussion Paper 2000/1, Sydney: University of New South Wales.

Diewert, W., 2005. Index number theory using differences rather than ratios. American Journal of Economics and Sociology 64, 347-395.

Färe, R., Grosskopf, S., Li, S.K., 1992. Linear programming models for firm and industry performance. Scandinavian Journal of Economics 94, 599-608.

Färe, R., Grosskopf, S., Lindgren, B., Roos, P., 1989. Productivity developments in Swedish hospitals: a Malmquist output index approach, in A. Charnes, V. W. Cooper, A. Lewin and L. Seiford (eds.), Data Envelopment Analysis: Theory, Methodology and Applications, Boston: Kluwer Academic Publishers.

Färe, R., Grosskopf, S., 2004. New Directions: Efficiency and Productivity, Kluwer Academic Publishers, Boston/London/Dordrecht. 
Färe, R., Primont, D., 2003. Luenberger productivity indicators: Aggregation across firms. Journal of Productivity Analysis 20, 425-435.

Färe, R., Zelenyuk, V., 2003. On aggregate Farrell efficiencies. European Journal of Operational Research 146, 615-620.

Farrell, M.J., 1957. The measurement of productive efficiency. Journal of the Royal Statistical Society $120,253-281$.

Førsund, F., Hjalmarsson, L., 1979. Generalised Farrell measures of efficiency: An application to milk processing in Swedish dairy plants. Economic Journal 89 (354), 294-315.

Grifell-Tatjé, E., Lovell, C.A.K., 1997. The sources of productivity change in Spanish banking. European Journal of Operational Research 2, 364-380.

Guironnet, J-P., Peypoch, N., 2007. Human capital allocation and overeducation: a measure of French productivity $(1987,1999)$. Economic Modelling 24, 398-410.

Guzmán, I., Reverte, C., 2007. Productivity and efficiency change and shareholder value: evidence from the Spanish banking sector. Applied Economics. DOI: $10.1080 / 00036840600949413$.

Humphrey, D.B., Pulley, L.B., 1997. Banks' responses to deregulation: Profits, technology, and efficiency. Journal of Money, Credit and Banking 29, 73 -93. 
Koopmans, T.C., 1957. Three essays on the state of economic analysis. McGraw-Hill (New York).

Kumbhakar, S.C., Heshmati, A., Hjalmarsson, L., 1999. Parametric approaches to productivity measurement: a comparison among alternative models, Scandinavian Journal of Economics 101, 3, 405-424.

Kumbhakar, S.C., Lozano-Vivas, A., Lovell, C.A.K., Hasan, I., 2001. The effects of deregulation on the performance of financial institutions: The case of Spanish savings banks. Journal of Money, Credit and Banking 33, $101-120$.

Kumbhakar, S.C., Heshmati, A., Hjalmarsson, L., 2002. How fast do banks adjust? A dynamic model of labour use with an application to Swedish banks. Journal of Productivity Analysis 18, 79-102.

Kumbhakar, S.C., Lozano-Vivas, A., 2005. Deregulation and productivity: The case of Spanish savings banks. Journal of Regulatory Economics 27, 3, 331-351.

Li, S.K., Cheng, Y.S., 2007. Solving the puzzles of structural efficiency. European Journal of Operational Research 180, 713-722.

Li, S.K., Ng, Y.C., 1995. Measuring the productive efficiency of a group of firms. International Advances in Economic Research 1, 377-390.

Luenberger, D.G., 1992. Benefit function and duality. Journal of Mathematical Economics 21, 461-481. 
Luenberger, D.G., 1996. Welfare from a benefit viewpoint. Economic Theory 7, 445462.

Malmquist, S., 1953. Index numbers and indifference surfaces. Trabajos de Estatistica 4, 209-242.

Maudos, J., Pastor, J.M., Quesada, J., 1996. Technical progress in Spanish banking: 1985-1994. University of Valencia and IVIE Discussion Paper, WP-EC 96-06.

Molyneux, P., Williams, J., 2005. The productivity of European co-operative banks. Managerial Finance 31, 11, 26-35.

Mukherjee, K., Ray, S.C., Millar, S.M., 2001. Productivity growth in large US banks: The initial post deregulation experience. Journal of Banking and Finance 25, 5, 913-939.

Nishimizu, M., Page, J.M., 1982. Total factor productivity growth, technological progress and technical efficiency change: dimensions of productivity change in Yugoslavia, 1965-78. The Economic Journal 92, 368, 920-936.

Odeck, J., 2007. Measuring technical efficiency and productivity growth: a comparison of SFA and DEA on Norwegian grain data. Applied Economics 39, 20, 2617-2630.

Park, K.H., Weber, W.L., 2006. A note on efficiency and productivity growth in Korean banking, 1992-2002. Journal of Banking and Finance 30, 2371-2386. 
Schure, P., Wagenvoort, R., O’Brien, D., 2004. The efficiency and the conduct of European banks: Developments after 1992. Review of Financial Economics 13, 371396.

Sealey, C., Lindley, J.T., 1977. Inputs, outputs and a theory of production and cost at depository financial institution. Journal of Finance 32, 1251-1266.

Shephard, R.W., 1970. Theory of Cost and Production Functions. Princeton University Press, Princeton NJ.

Stiroh, K.J., 2000. How did Bank Holding Companies Prosper in the 1990s? Journal of Banking and Finance 24, $1703-1745$.

Wagenvoort, R., Schure, P., 1999. Who are Europe's efficient bankers? EIB Cahiers Papers 4, 1, 105-126.

Williams, J., 2001. Financial deregulation and productivity change in European banking. Revue de la Banque 8, 470-477.

Williams, J., 2004. Determining management behaviour in European banking. Journal of Banking and Finance 28, 2427-2460.

Williams, J., Gardener, E.P.M., 2003. The Efficiency of European Regional Banking. Regional Studies 37, 4, 321-330. 
Varian, H.R., 1984. The nonparametric approach to production analysis. Econometrica 52, 579-597.

Ylvinger, S., 2000. Industry performance and structural efficiency measures: Solution to problems in firm models. European Journal of Operational Research 121, 164-174. 
Table 1: Number of Saving Banks \& Observations: by Country, 1996-2003

\begin{tabular}{lrrrrrrrrr}
\hline & 1996 & 1997 & 1998 & 1999 & 2000 & 2001 & 2002 & 2003 & Total \\
& & & & & & & & & \\
Austria & 13 & 65 & 66 & 67 & 67 & 67 & 65 & 65 & 475 \\
Belgium & 15 & 14 & 14 & 13 & 12 & 11 & 10 & 7 & 96 \\
Finland & 1 & 1 & 1 & 1 & 1 & 1 & 1 & 1 & 8 \\
France & 22 & 22 & 22 & 29 & 30 & 30 & 30 & 28 & 213 \\
Germany & 592 & 584 & 588 & 572 & 556 & 527 & 490 & 233 & 4,142 \\
Ireland & 3 & 3 & 3 & 3 & 3 & 2 & 2 & 2 & 21 \\
Italy & 58 & 58 & 58 & 57 & 54 & 56 & 53 & 13 & 407 \\
Luxembourg & 1 & 1 & 1 & 1 & 1 & 1 & 1 & 1 & 8 \\
Portugal & 3 & 3 & 3 & 3 & 3 & 3 & 3 & 2 & 23 \\
Spain & 30 & 38 & 39 & 39 & 39 & 41 & 42 & 46 & 314 \\
All banks & 741 & 792 & 798 & 787 & 767 & 740 & 698 & 398 & 5,721 \\
\hline
\end{tabular}

Source: BankScope. 
Table 2: Descriptive Statistics: ECU million (inflation-adjusted); 1996-2003

\begin{tabular}{|c|c|c|c|c|c|c|c|}
\hline \multirow[b]{2}{*}{ Country } & \multirow[b]{2}{*}{ Statistic } & \multicolumn{2}{|c|}{ Inputs } & \multicolumn{4}{|c|}{ Outputs } \\
\hline & & Fixed & Variable & Customer & Interbank & Securities & OBS \\
\hline & & Assets & Cost & Loans & Loans & & \\
\hline \multirow[t]{2}{*}{ AUS } & Average & 31.84 & 151.35 & 106.65 & 500.96 & 1158.33 & 437.89 \\
\hline & Std dev & 477.56 & 101.43 & 5394.75 & 2013.42 & 2775.96 & 353.19 \\
\hline \multirow[t]{2}{*}{ BEL } & Average & 41.65 & 142.40 & 304.18 & 2145.77 & 603.82 & 2774.39 \\
\hline & Std dev & 2534.47 & 754.27 & 5442.54 & 1755.04 & 5515.38 & 10618.43 \\
\hline \multirow[t]{2}{*}{ FIN } & Average & 121.90 & 35.67 & 133.71 & 1847.04 & 79.70 & 591.31 \\
\hline & Std dev & 144.78 & 23.88 & 511.51 & 37.69 & 64.89 & 34.71 \\
\hline \multirow[t]{2}{*}{ FRA } & Average & 140.82 & 436.59 & 927.54 & 6163.41 & 7790.45 & 2886.08 \\
\hline & Std dev & 2029.34 & 2856.36 & 19105.14 & 22436.73 & 9152.78 & 7320.11 \\
\hline \multirow[t]{2}{*}{ GER } & Average & 25.45 & 29.19 & 90.39 & 986.83 & 141.62 & 459.35 \\
\hline & Std dev & 123.06 & 110.26 & 1273.27 & 232.45 & 564.97 & 352.79 \\
\hline \multirow[t]{2}{*}{ IRL } & Average & 66.33 & 17.43 & 192.51 & 3267.36 & 876.31 & 230.85 \\
\hline & Std dev & 210.80 & 67.39 & 1692.92 & 537.50 & 142.74 & 459.82 \\
\hline \multirow[t]{2}{*}{ ITA } & Average & 65.00 & 118.83 & 219.08 & 2047.21 & 680.18 & 765.14 \\
\hline & Std dev & 683.90 & 538.65 & 4921.22 & 2386.20 & 1682.09 & 2632.85 \\
\hline \multirow[t]{2}{*}{ LUX } & Average & 256.04 & 7.37 & 2108.30 & 7136.39 & 11464.76 & 12547.76 \\
\hline & Std dev & 3161.56 & 535.61 & 773.52 & 751.90 & 2417.59 & 251.06 \\
\hline \multirow[t]{2}{*}{ PTE } & Average & 417.73 & 462.52 & 1387.81 & 15055.90 & 3162.62 & 4278.01 \\
\hline & Std dev & 12672.90 & 1545.38 & 15622.75 & 4138.03 & 5779.96 & 17910.01 \\
\hline \multirow[t]{2}{*}{ SPA } & Average & 267.44 & 455.57 & 488.61 & 6366.27 & 977.47 & 2380.87 \\
\hline & Std dev & 509.88 & 814.40 & 9791.04 & 1931.48 & 3948.66 & 1017.13 \\
\hline
\end{tabular}


Table 3: Average annual productivity growth, $\%$ :

European Savings Banks (1996-2003)

\begin{tabular}{|l|r|r|r|} 
Country & $\begin{array}{c}\text { Aggregate } \\
\text { Luenberger } \\
\text { (AL) }\end{array}$ & $\begin{array}{c}\text { Efficiency } \\
\text { change } \\
\text { (EFFCH) }\end{array}$ & $\begin{array}{c}\text { Technical } \\
\text { change } \\
\text { (TECH) }\end{array}$ \\
\hline Austria & 2.020 & 0.000 & 2.020 \\
\hline Belgium & 3.183 & 0.000 & 3.183 \\
\hline Finland & 4.530 & 0.000 & 4.530 \\
\hline France & 4.223 & 0.000 & 4.223 \\
\hline Germany & -1.688 & 0.000 & -1.688 \\
\hline Ireland & 3.860 & 0.000 & 3.860 \\
\hline Italy & 2.383 & 0.530 & 1.853 \\
\hline Luxembourg & 1.741 & 0.000 & 1.741 \\
\hline Portugal & 3.179 & 0.820 & 2.359 \\
\hline Spain & 4.488 & 1.871 & 2.616 \\
\hline Mean & 2.791 & 0.323 & 2.470 \\
\hline Median & 3.181 & 0.000 & 2.488 \\
\hline Std Dev. & 1.865 & 0.616 & 1.770 \\
\hline & & & \\
\hline
\end{tabular}

